THE MODERN SEX DOLL-OWNER: A DESCRIPTIVE ANALYSIS

\author{
A Thesis \\ presented to \\ the Faculty of California State Polytechnic University, \\ San Luis Obispo
}

\begin{abstract}
In Partial Fulfillment
of the Requirements for the Degree

Master of Science in Psychology

by

Sarah Valverde (formerly Schewe)
\end{abstract}

August 2012 
(C) 2012

Sarah Valverde

ALL RIGHTS RESERVED 


\section{COMMITTEE MEMBERSHIP}

TITLE: The Modern Sex Doll-Owner: A Descriptive Analysis

AUTHOR: Sarah Valverde

DATE SUBMITTED: August 15, 2012

COMMITTEE CHAIR: J. Kelly Moreno, Ph.D.

COMMITTEE MEMBER: Michael Selby, Ph.D.

COMMITTEE MEMBER: Jason Williams, Ph.D. 


\title{
ABSTRACT \\ THE MODERN SEX DOLL-OWNER: A DESCRIPTIVE ANALYSIS
}

\author{
Sarah Valverde
}

Over the last fifteen years, the sex doll industry has grown from producing inexpensive novelty items to creating a multimillion-dollar global industry featuring high- quality, realistic love dolls. These dolls are designed and advertised for sexual stimulation, companionship, artistic representations of human fantasy, and other creative pursuits, such as photography. Made of flesh-like silicone, modern sex dolls sell from $\$ 3,500-\$ 10,000$.

The use of human simulacra for sexual stimulation is an enduring practice. However, the psychological community has said little on the subject. Early sexologists briefly reference Agalmatophilia or Statuphilia, a rare sexual attachment to statues. Today, the sex doll phenomenon appears increasingly prevalent across the globe. Media coverage of this phenomenon has been featured in online magazines, television programs, music, documentaries and major motion pictures. More often than not, sex dollownership is portrayed as pathological. Sex doll-owners are members of a marginalized population, and accessing the population is challenging as many members of the community wish to remain anonymous for fear of judgment, persecution, and psychiatric labeling.

The purpose of this study was to increase psychology's understanding of this interesting and growing population. Specifically, a 45-item online survey addressing demographics was constructed and assessed. Additionally, participants were asked to describe their relationship status, doll-ownership status, and satisfaction with human and sex doll partners, including sexual satisfaction and performance. Quality of life was also assessed via the Satisfaction with Life Scale (SWLS).

Sixty-one participants were recruited from an online doll-owner community forum. It was hypothesized that most doll-owners sampled would be middle-aged, White, single, heterosexual males who are neither significantly better nor worse in terms of psycho-sexual functioning and life satisfaction than the general population. Descriptive data and statistical analysis partially supported the hypotheses. Implications and future direction are discussed, as are methodological considerations.

Keywords: sex doll, love doll, Pygmalionism, agalmatophilia, statuephilia, marginalized population, sexuality research 


\section{ACKNOWLEDGEMENTS}

I would like to thank everyone who supported this project from conception to completion over the past two years. I am especially grateful to my thesis committee chair, Dr. J.K. Moreno for his good humor, guidance and encouragement. Thank you to Dr. Jason Williams and Dr. Michael Selby for their guidance in research design and statistics. A special thanks to Dr. Jennifer Teramoto Pedrotti for her generosity and willingness to assist in statistical analysis, SPSS, and for her expertise on multicultural factors in research design. Thank you to Dr. Gary Laver, Cal Poly's resident statistical guru. Thank you to Dr. Lisa Sweatt whose instruction, academic advising, and clinical supervision have been the crux of my graduate experience. Lastly thank you to my husband, Michael Valverde, for his cheerleading, love, and excellent editing skills, and to my son, Maximilian, for being born and for keeping me on my toes. 
List of figures.......................................................... vii

\section{CHAPTER}

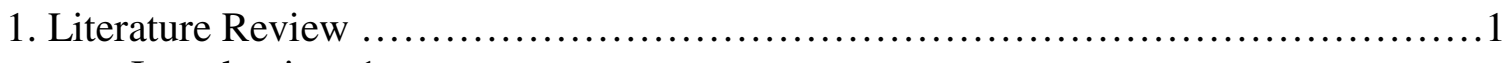

Introduction, 1

Historical Factors, 2

Early Sexolgists, 6

Sociocultural Factors, 8

Commercial Considerations, 9

The Dolls, 9

Manufacturers, 10

Doll-Owners, 14

Arts and Media, 16

Professional Attention, 20

Ethical Considerations, 23

Research Questions, 24

Hypotheses, 25

2. Methods.

Participants, 27

Materials, 27

Procedure, 28

3. Results.............................................................. 30

4. Discussion................................................................ 34

Summary of Significant Results, 34

Professional Implications, 35

Diagnostic and Treatment Implications, 37

Sociocultural Implications, 38

Methodological Issues and Limitations, 39

Future Directions, 42

Conclusion, 43

References

Appendices

A. Informed Consent Form............................................50

B. Responses to Survey Posting.....................................52 


\section{List of Figures}

Figure $\quad$ Page

1. Figure 1. Abyss Creations "Rui Doll” Face: 14, Body: 2, Skin Tone: Tanned,

Wig color/Style: Custom........................................13

2. Figure 2. Puppenfetisch nach Alma Mahler, 1919..........................19

3. Figure 3. Oskar Kokoschka, Mann mit Puppe .............................20 


\section{CHAPTER ONE}

\section{Literature Review}

\section{Introduction}

Over the last fifteen years, the sex doll industry has grown from producing inexpensive novelty items to creating a multimillion-dollar industry featuring high-end realistic love dolls. Manufacturers and consumers of this product are located around the globe. Since 1996, the most renowned U.S. sex doll company has sold over 3,500 dolls worldwide, and in 2009 earned more than 2 million dollars in sales (Abyss Creations, personal communication, October 4, 2010). Made of flesh-like silicone, modern sex dolls sell at prices of $\$ 3,500-\$ 10,000$ (USD). Although the primary function of these dolls is ostensibly sexual in nature, doll-owners have described varying levels of emotional attachment to their sex dolls, from identification of their doll as a life partner, to describing their doll as a mere novelty item.

The term "sex doll" is used throughout this paper, and refers to modern, high-end dolls designed with sexual stimulation capabilities. These dolls are differentiated from low-cost inflatable plastic dolls by their realistic design, size, and high level of craftsmanship. Although not all doll-owners use their doll as a masturbation tool, the term sex doll is used here to denote a difference from those dolls not designed for sexual penetration/stimulation. It should be noted that in addition to the term sex doll, other common terms for these dolls include love dolls, Dutch wives, silent wives, synthetic partners, and gynoids. The word Polymerisian was recently coined by the doll-owning community and defined in Urban Dictionary (www.urbandictionary.com) with good humor as "[a]ny person made with a synthetic polymer silicone skin with a rigid and jointed skeleton." The term "sex doll" is not limited to dolls created with female sex 
organs, but can include male, transgender and intersex dolls, as well. Throughout this paper, the term doll-owner is used to describe those individuals who currently own a modern sex-doll.

The sexual use of inanimate objects designed in human likeness has deep historical roots. Accounts of Agalmatophilia, the pathological condition in which some people establish exclusive sexual relationships with statues, dates back to ancient Greece (Scobie \& Taylor, 1975). Nonetheless, there has been no investigation into whether consumers of the modern sex doll are mentally or emotionally disturbed. Neither has there been a professional discussion regarding the modern day equivalent of Agalmatophilia as a diagnosable and treatable condition. Wider prevalence of dollownership provides an opportunity to gather information while engaging in this professional discussion.

Although this is a burgeoning cross-cultural phenomenon, the availability of organized information on the doll-owning population is limited. The doll-owning community is a minority population which is marginalized by society and frequently pathologized by professionals (Schewe \& Moreno, 2011). To date, there have been no empirical investigations to inform our understanding of doll-ownership.

\section{Historical Factors}

The creation of a human form for the purposes of sexual gratification is an ancient and enduring practice. Technology has been instrumental in increasing verisimilitude. As technology continues to discover new ways of animating objects through robotics, and in computer programs designed to replicate human emotion, we will see further changes to the presentation of this phenomenon. The basic form remains unchanged, although 
new fabrication technologies and materials create a much greater realism than ever before.

Although the modern silicone sex doll is only around 15 years-old, the literary history of sex dolls is much older. The ancient Greeks described a phenomenon referred to as Agalmatophilia, or statue love. Agalmatophilia is not to be confused with the fictional and supernatural powers of those who bring a statue to life, referred to as Pygmalionism (Scobie \& Taylor, 1975). However, several sex researchers have referred to use of artificial human forms for sexual purposes as Pygmalionism. Pygmalionism is referenced by Henry Havelock Ellis in his Studies in the Psychology of Sex:

Pygmalionsim, or falling love with statues, is a rare form of erotomania founded on the sense of vision and closely related to the allurement of beauty. (I here use "pygmalionism" as a general term for the sexual love of statues; it is sometimes restricted to cases in which a man requires of a prostitute that she shall assume the part of a statue which gradually comes to life...(p. 188)

According to Ovid's Metamorphoses, book X, Pygmalion was a misogynist who sculpted a perfect woman out of ivory. The goddess Venus, so flattered by the ivory woman's resemblance to her, brought the statue to life as a gift to Pygmalion. The story of creating a perfect female has its modern expression in the play Pygmalion, by George Bernard Shaw, and similar Pygmalionist themes are found in Weird Science (1985), and Ira Levin's film, The Stepford Wives (1972). In both films technology provides the tools for man to design or program a "perfect" living woman.

Statuephilia and statue syndrome are other terms used to describe the use of statues for sexual gratification or "the pathological condition in which some people establish exclusive sexual relationships with statues" (Krafft-Ebing, 1965/1978, p. 351). 
Statues in ancient Greece and Rome were often placed at street level, tinted with accurate colors, and displayed free of barricades, (Ellis, 1942) (Hersey, 2009), thereby making them more lifelike and accessible to touch than most statues today. Statues and life-sized automata were incorporated in religious and sex practices in ancient times. Ptolemaic statue marriages of ancient Greece occurred when a ruler or religious leader wed a statue of Aphrodite (Hersey, 2009). Ancient literary and historical accounts describe the sexual use of statues and automata in Dionysian orgies (Hersey, 2009).

In Philostratus's Lives of the Sophists, Onomarchus of Samos, referred to as "the man who fell in love with a statue," makes the following speech: "O living loveliness in a Lifeless body, what deity fashioned you?...For truly nothing is lacking in you, the expression on the face, the bloom of the skin, the sting in the glance, the charming smile..." (as cited in Scobie \& Taylor, 1975, p. 52). In Euripides’ Alcestis, Admetus says to his wife, who is about to sacrifice her life for his:

I shall find a clever sculptor to carve your likeness and it shall be hid in our bed. I shall kneel beside it and throw my arms around it and say your name 'Alcestis, Alcestis!' and think that I hold my dear wife in my arms, snatching at cold comfort to ease the weight from my heart! (as cited in Scobie \& Taylor, 1975, p.50)

The modern sex doll may has a direct antecedent in the cotton sex doll created and used by sailors on long voyages, referred to as dames de voyage (Bloch, 1908; Ferguson, 2010; Wolf, 2010). These dolls were created by French and Spanish sailors during the height of their naval empires in the seventeenth century (Ferguson, 2010). The navies of Imperial Germany and Japan reportedly sanctioned the widespread use of dames de voyage, as preferable to homosexuality. Both navies reportedly manufactured their own versions of the dames de voyage (Wolf, 2010). 
A popular urban legend claims the German navy became the first creator of the modern sex-doll, Model Borghild (Ferguson, 2010; Lenz, n.d.; Pulham, 2008; Wolf, 2010). According to rumor and urban myth, the doll was part of the Nazi's "fieldhygienic project," initiated to counterbalance the sexual drive of storm troopers (Lenz, n.d.). However, the existence of the author, "Lenz", and the reports on the so-called Borghild doll are unverifiable, and are possibly hoaxes (Ferguson, 2010; Schewe \& Moreno, 2011). The Japanese had a version of a dames de voyage, called a do-ningyo. A description is cited from a Japanese work titled "The Art of Quickly Seducing a Novice" in Tabori's book, The Humor and Technology of Sex (1969):

A man who is forced to sleep alone can obtain pleasure with a do-ningyo. This is the body of a female doll, the image of a girl of thirteen or fourteen with a velvet vulva. But these dolls are only for people of high rank. (p. 337)

Dolls and statues created and used for sexual purposes are cross-cultural phenomena in various forms for centuries. The absence of historical information about production, distribution, and sales, or customer satisfaction data on sex dolls leaves the history of sex dolls open to considerable speculation. Until the emergence of the modern sex dolls, records of sales are found only in rumored accounts of sex doll use, and antique advertisements, such as the one translated by Henry Carey from a Paris circular in 1902. It advertises the sale of a complete, custom sex doll made to fit customer specifications: "All moves, arms, legs, buttocks, head, eyes; a perfect likeness of the person whose photograph is sent...the complete apparatus, guaranteed against breakage, man or woman, 3000 francs" (Cary, 1922, p. 50). 


\section{Early Sexologists}

Pioneers in the field of sexology in the early $20^{\text {th }}$ century such as Iwan Bloch, Havelock Ellis, Richard von Krafft-Ebing, and Magnus Hirschfeld, have referenced statue love in their research. A French journal dated March $4^{\text {th }}, 1877$ published a story which describes the case of a gardener who falls in love with a statue of Venus de Milo and was found attempting coitus with it (Krafft-Ebing, 1965/1978). Krafft-Ebing describes these types of acts: "Violation of statues...they always give the impression of being pathological...these cases stand in etiological relation with abnormally intense libido and defective virility or courage, or lack of opportunity for normal sexual gratification" (p. 351). Hirschfeld's Sexual Pathology (1940) considers Pygmalionism as inclusive of more "primitive" human simulacra than statues:

To be sure the nature of Pygmalionism does not exhaust itself in love of statues as such, but also in the artificial, and occasionally artistic, construction of a figure corresponding to the inner desire whose sight and contact, which may go so far as actions similar to cohabitation, bring about physical and psychic relief...I have seen dolls which a prisoner made as a substitute for a woman. We are justified only to a certain extent in speaking of hypereroticism in such makeshift intercourse. (p. 226)

Hirschfeld goes on to differentiate between a type of "makeshift intercourse" and fetish: "hypererotic excitation is evoked usually not only through the similarity to humanity alone, but through some special property of the statue, much as the necrophile is attracted to the course by the cool skin..." (Hirschfeld, 1940, p. 227).

Although early sexologists reference statue love, they provide no psychological case studies to support their opinions. The Kinsey Institute also fails to provide specific information on the use of life-sized sex dolls but does report on the use of sex "devices." The Kinsey Data: Marginal Tabulations of the 1938-1963 Interviews, conducted by the 
Institute for Sex Research, reported on male masturbatory techniques involving "devices": 7\% of white college males, $5.5 \%$ of White non-college males, and 1.8\% of black college males reported "frequent use of devices: any sadomasochism, any highly unusual technique" (Gebhard et al. 1979, p. 213). Doll or statue use presumably fall into this category since sex dolls were not explicitly mentioned anywhere in the research.

Scobie and Taylor (1975) speculated agalmatophilia may simply have changed form from statues to plastics: "Tentatively, it could be argued, over a few thousand years mankind has dropped at least one pathological condition, agalmatophilia, from its repertoire of pathologies...Only six cases of agalmatophilia have been documented in the last two centuries" (p. 49-50). In criticism of Scobie and Taylor and early sexologists, White (1978) writes:

Early scientific researchers of sexual behavior appear to have sometimes confused fantasy (the process of imagining objects or events in terms of imagery) with perversion (sexual behavior which differs widely from normal standards and which is typically prohibited by law). This is certainly true of agalmatophilia. (p. 249)

Although the professional psychological community has just begun to investigate sex dolls and their owners, it is clear the existence of sexual behavior similar to agalmatophilia is more than mere fantasy. This investigator found two dissertations and one master's thesis on the topic of artificial women (de Fren, 2008), sex doll fashion and identity formation (Itagaki, 2011), and artificial vaginas and sex dolls (Moya, 2006) written by scholars in philosophy, fashion, and human sexuality, but could locate no published psychological paper on the topic of modern sex dolls to date. In the absence of empirical data on modern day doll-owners, the bulk of the information for this paper was found across various areas of study, including online magazine articles, motion picture 
documentaries, movies, blogs, online forums, personal interviews, and surveys. With that in mind, the existing material on modern sex dolls and their owners can be usefully divided and examined with respect to the following areas: sociocultural, commercial, arts and media, professional, and ethical considerations.

\section{Sociocultural Factors}

Doll manufacturers exist in several countries including Russia, Germany, France, Japan, the United Kingdom, and the United States. Japan and the U.S. are the undisputed leaders in the sex doll industry. Approximately 20 doll companies exist between Japan and the United States. There has been no research to date concerning prevalence rates of doll-ownership in individual countries.

Japan is at the forefront of the sex doll industry, creating magazines, doll exchange parties, and doll photography societies (Galbraith, 2008). "Love doll” escort services have emerged which provide access to sex dolls without the high cost of ownership (Ferguson, 2010). In South Korea and Japan, one can rent a doll for approximately $\$ 100$ per hour (Levy, 2008). Orient Industry is the most well-known sex doll manufacturer in Japan. Their Candy Girl series (supple silicon flesh over flexible metal skeletons) is well-known (Galbraith, 2008). Japan may demonstrate a level of cultural acceptance of the western world lacks. A history of accepted, even venerated, prostitution is found in the history of the geisha, in contrast to laws in the U.S. which prohibit prostitution. Currently Asia is the only continent where known sex doll brothels exist.

An article in Japan Today describes a sex doll funeral called a ningyo kuyo. The funeral commemorates sending the doll unit to a factory for dismantling after the original 
owner was married. The owner of Orient Industry, a doll manufacturer in existence for over 30 years, describes the ceremony: "Now she will return to her factory home like 'satogaeri,' the ex-wife going back to her family" (Galbraith, 2008). Japan Today reports Japan has used dolls for religious purposes since 1000AD.

According to Orient Industry, the company sells approximately 50-80 dolls per month and estimates there are over 20,000 doll-owners in Japan alone (Galbraith, 2008; Maeda, 2007). A spokesman for Orient Industry reports that nearly all of the people who buy these dolls are single men and about 60 percent of them are over the age of 40 (Maeda, 2007). "Nowadays, women are sometimes more dominant than men in the real world, and they don't always pay attention to men," said Hideo Tsuchiya, the company's president. "More and more men are finding themselves miserable so we're making these dolls partly in support of men"(Maeda, 2007). Since the 1950's the Japanese government began using sex dolls to enhance the lives of its workers in remote outposts such as the South Pole (Galbraith, 2008).

\section{Commercial Considerations}

\section{The Dolls}

Online, anyone can purchase a hyper-realistic, life-sized silicone sex doll and customize it to one's aesthetic, gender, and sex preferences. These dolls weigh between 40 to $120 \mathrm{lbs}$, have moveable joints, and some are equipped with a complete skeletal system made of stainless steel. Most doll manufactures offer a variety of faces, body types, breast size, eye-color and makeup styles. Some doll companies have additional features to choose from such as a customizable clitoris, artificial milk glands, pressure released urination, and an insertable hymen. The option to create a transgendered doll is also available with some doll lines. 
A few doll manufacturers have incorporated computer software to automate dolls, enabling them to respond to vocal commands and facial recognition. They can be programmed with a facsimile of a personality. Roxxxy is one such doll, advertised as having five programmable personalities: Wild Wendy, Frigid Farrah, Mature Martha, S\&M Susan and an unnamed personality that is considered more "naïve" (Somaiya, 2010). Douglas Hines, founder of the Lincoln Park, N.J. based True Companion LLC, said Roxxxy can carry on simple conversations." Sex only goes so far - then you want to be able to talk to the person," Hines said (Roxxxy Sex Robot, 2010).

First Androids, a German based sex doll manufacturer, offers additional motorized features for dolls, such as automatic tongues with various movement capabilities, automated toes for stimulation, eyes equipped with video recording devices, simulated respiration and heart beats, vocal reactions to genital penetration, and an automated pulse that can be felt at the wrist and carotid artery. This information is found on their website www.first-androids.de.

\section{Manufacturers}

The sex doll industry has been transformed by advances in computer generated images (CGI) and silicone technology. Hollywood special effects technicians began using advances in these technologies to create realistic corpses for films (Ferguson, 2010). These mannequins were the beginnings of the realistic, functional sex doll. Although the origins of the industry are known, other details about the business of sex doll manufacturing are less clear. Over 25 websites offer dolls, parts, and/or other accessories for purchase. Prevalence rates of sales reported by manufactures are difficult 
to obtain. With the exception of Abyss Creations, none of the doll manufacturers contacted for this paper would disclose specific sales information.

Abyss Creations manufactures a carefully-crafted, fully functional sex doll called a Real Doll. Abyss Creations offers customers a choice of 13 body types, 16 faces, five skin tones, 11 eye-colors, and 8 different hair-colors. The company was founded in 1996 by Matt McMullen, a visual artist. Abyss Creations is located in San Marcos, California, and produces about 400 dolls per year. Most Real Dolls are sold within the United States, with the majority of sales in California, Florida, and Texas. Following the United States, Germany and Great Britain are Abyss Creations' largest international markets, with Japan and Canada close behind (Abyss Creations, personal communication, August $5,2010)$.

To order a Real Doll online, the buyer first chooses a body type ranging in height from 4' 10 " to 5'6". Each body type has its own unique measurements, offering a variety of breast-cup, waist, hip, and foot sizes. Next, the buyer chooses face type, skin tone, eye color, eye-makeup, lip color, nail color, hair color and style, and, finally, pubic hair. All information concerning Real Dolls is found at the Abyss Creations website, www.realdoll.com. At additional cost, the buyer may opt to enlarge breasts, purchase "hi-realism eyes," or add custom freckles. Shipping is \$500 USD within the continental United States, and $\$ 850$ to $\$ 1050$ USD outside. All sales are final.

Abyss Creations also takes custom orders: "We have made a number of pixie/elf type dolls with pointed ears and specialty eyes, and also dolls with vampire fangs. We also have made a number of transsexual and hermaphrodite dolls, most commonly with male genitalia on a female form" (Abyss Creations, personal communication, October 4, 
2010). Male dolls are also available at Abyss Creations; however, there are only two body and three face types from which to select. Abyss Creations reports that although they sell half torsos and faces with oral cavities, their most popular items are full sized female dolls:

A standard doll costs $\$ 5,999$ USD...These orders start at $\$ 12,000$ for just a custom face to over $\$ 50,000$ for a custom face and body. We have made dolls of this sort for artists and television shows as well as other projects...We have also rented and sold dolls to several movies and television shows, most notably the Oscar nominated Lars and the Real Girl, CSI: New York, My Name is Earl, Reno 911!, and most recently, Rizzoli and Isles (Abyss Creations, personal communication, October 4, 2010).

Abyss Creations sales show that their most popular doll is the Rui doll, a Body 2, Face 14 type (see figure 1). 


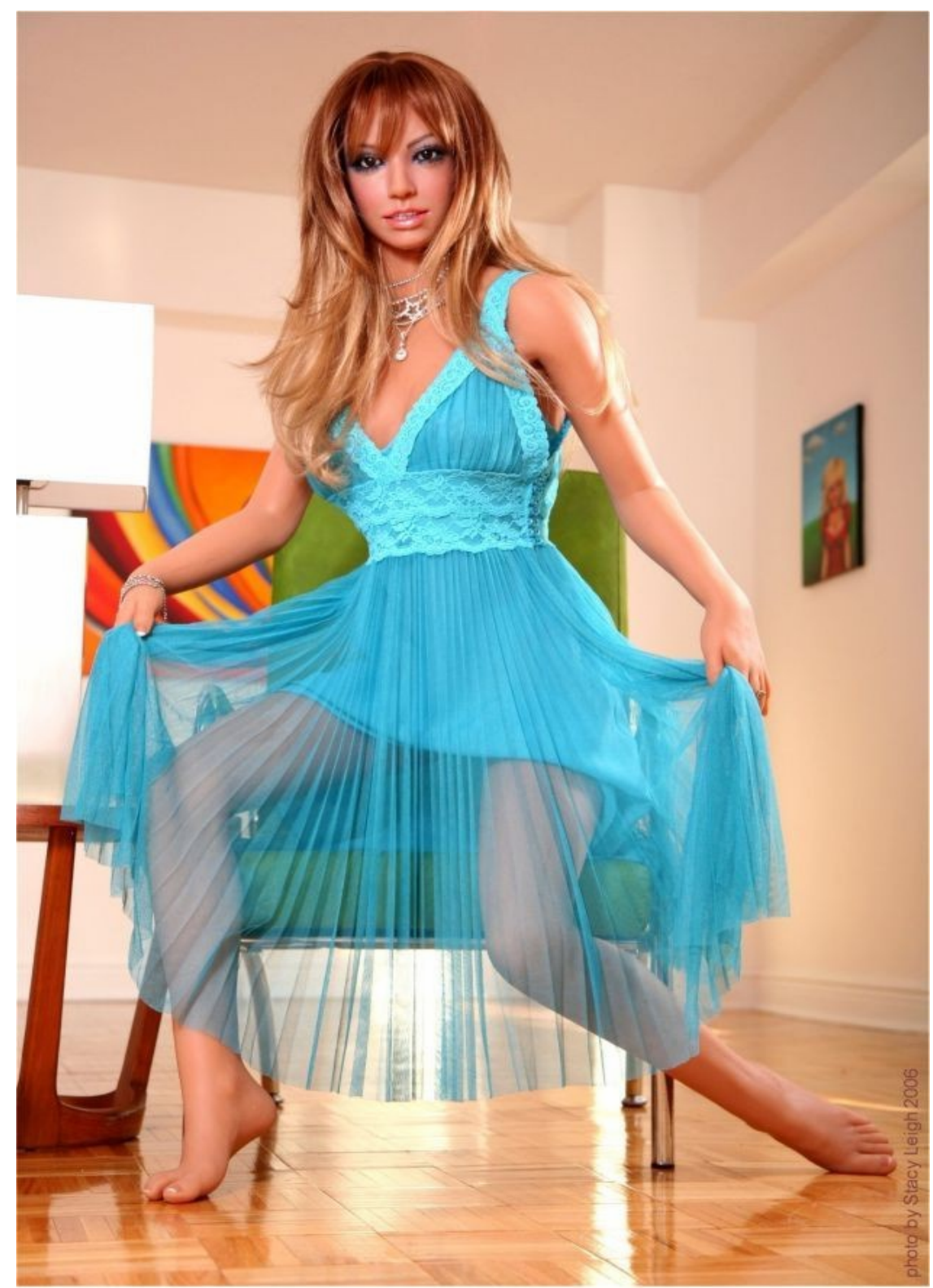

Face: 14

Body: 2

Skin tone: Tanned

Eye color: Brown

Wig color/style: Custom color 0701

Makeup: Slate shadow, heavy black liner

Lips: Natural

Fingernails: French Manicure

Outfit: Unavailable

Figure 1

"Rui Doll" Face: 14, Body: 2, Skin Tone: Tanned, Wig color/Style: Custom, http://www.realdoll.com/cgibin/snav.rd?action=viewgalleryimage \&gallery=rui\&image=r ui_set3_6.jpg. Photo by Stacy Leigh, 2006 


\section{Doll Owners}

In their review of the literature, Schewe and Moreno (2011) said, according to doll manufacturers Abyss Creations (US) and Orient Industries (Japan), the primary age and sex of their customers are males ages 40-65. Abyss Creations speculated some reasons for owning a doll: appreciation of the dolls for their artistic value, companionship, and sexual gratification. Abyss Creations reports that some people purchase dolls after the end of a relationship due to death or divorce. Although some doll-owners report being in relationships Orient Industries speculates most of their customers are single (Itagaki, 2011). As cited in Schewe and Moreno (2011), the online forum “The Doll Forum” (www.thedollforum.com) posted a poll for members titled, "What is your relationship status?" Two hundred members responded: Single—with doll (75); Dating or in a relationship—with doll (17); Married—with doll (30); Divorced— with doll (16); Widowed—with doll (6); Single—without doll (20); Dating or in a relationship—without doll (9); Married—without doll (16); Divorced—without doll (7).

Sex-doll manufacturers, Matt Krivicke \& Bronwen Keller (2012), described dollowners as individuals who vary in their reasons for purchasing a doll. They described sex dolls as enhancing the quality of life for doll-owners, and as therapeutic devices to relieve suffering from sexual dysfunction and/or intimacy issues. Further, Krivicke and Keller reported that many of their past clients suffered from physical disabilities.

Schewe and Moreno (2011) report not all doll-owners have sex with their dolls. Among those who do have sex with their dolls, not all owners use their dolls as their only source of sexual excitement or gratification. Some doll-owners are in relationships with 
one or more living partners and use their dolls purely as a masturbation tool or as a supplement to their "normal" sexual relationships.

A graduate student at Stockholm University Centre for Fashion Studies, Azusa Itagaki personally interviewed several doll-owners for her master's thesis, Inside the Dollhouse: Fashion and the Creation of Identity. One Japanese interviewee reported he never had sexual intercourse with his many dolls (he owns more than ten), but rather uses dolls as subjects for his photography. A French man in his forties, who owns one doll (Emy), reported purchasing his doll after his mother died, "Emy is a presence for me in this flat. I needed Emy for this new apartment without my mother... I always fell in love with the girls I lived together with, but one day I told myself to stop because I was too sad to have a relationship anyway. I wanted to live without women. This is why I have Emy” (Itagaki, 2011, p. 26).

The Guys and Dolls documentary showcased doll-owners who reported their doll(s) improved or even "saved" their lives. One thirty-two year-old man said, "I can tolerate being alone, but not loneliness" (Flintoff \& Raphael, 2006). Another forty-one year-old man enjoyed sex with his dolls, but mostly valued the "peace of mind" they brought him. He stated, "I will never be used again” (Flintoff \& Raphael, 2006).

Salon Magazine interviewed the aforementioned doll-owner, asking how his two dolls have affected his life. He said, "I don't like being around people at all now...the less human contact I have the happier I am...I feel safer and more secure knowing that I will never waste my time and money on another human female that just wants to use me." He added, "I don't have a lot of human friends, and only two of them have seen Ginger and Kelly" (Laslocky, 2005). 
Several female doll-owners have identified themselves on online forums and in media interviews. Elisabeth Alexandre's book, Des Poupees et des Hommes, includes an interview with a heterosexual couple from the Midwest. Both husband and wife own sex dolls. The female doll-owner reported her long-held fascination for dolls began after suffering trauma at age 10. Imagining she is a doll has helped her endure other traumas such as eye surgery. There are a limited number of female doll-owners represented in the media and literature. Women may be less likely to purchase sex dolls for a variety of reasons. Many women may not know about sex dolls. Doll companies derive most of their sales from male customers and market accordingly. Where there are many choices for female doll body-type and aesthetics, male dolls come in limited designs. Modern sex dolls can weigh up to $150 \mathrm{lbs}$ and may be difficult to maneuver for a person with a small stature. Women may not be attracted to sex dolls at the same rate as some men, and may be less inclined to consider buying a sex doll due to cultural factors and stigma associated with female sexuality.

\section{Arts and Media}

The media has tracked the new millennium dolls with great interest, showcasing them on U.S. television shows such as Nip/Tuck. A doll is a protagonist of the feature length film Lars and the Real Girl, which premiered at the 2007 Toronto Film Festival. The film highlights the psychological connection between a man and his doll. The synopsis of the film found on the film's packaging reads:

...instead of seeing a sex object, Lars sees in this doll a potential life partner and the only kind of social "peer" he can relate to. So Lars orders a doll, whom he names Bianca, and begins treating her with utmost gentlemanly respect -- and as though she's his real-life, flesh-and-blood girlfriend. As he begins bringing Bianca with him everywhere he goes, the townspeople have to find just the right 
balance between supporting Lars' unusual romance and trying to introduce him to a more conventional partner. (Gillespe, 2007)

A National Geographic television program, Taboo, aired an episode featuring the relationship between a Real Doll and a middle-aged man. The episode is titled "Strange Love." National Geographic describes the program as a series which "crosses the barriers of modern society and explores the diversity of the human race where the secret, sacred, and eccentric are part of the everyday experience of humanity." The doll-owner in this show was also featured in TLC's television series My Strange Addiction. TLC describes the episode, saying "[Owner] treats his life-size doll like a human wife. He eats meals with her, shops for her, dresses her and is convinced she returns the same type of affection."

Guys and Dolls, a documentary created in 2006, details the lives of several dollowners who describe varying degrees of loneliness, shyness, and distrust in others. References to sex dolls are similarly represented in music lyrics and visual art. In 1997, British band, Duran Duran, released the song "Electric Barbarella" in 1997:

I knew when I first saw you on the showroom floor/You were made for me/I took you home and dressed you up in polyester/ Princess of my dreams/Emotionless and cold as ice/All of the things I like /The way you look/ The way you move/ The sound you're makin'/ In ultra-chrome, latex and steel.

As mentioned in Schewe \& Moreno (2011), Austrian-born artist and poet Oskar Kokoschka commissioned the creation of a life-sized, anatomically correct, female doll in 1918 from toy manufacturer Hermione Moos (see figure 2). The commission followed the end of a contentious, long-time romantic relationship with music composer and Viennese socialite, Alma Mahler. The stress of the breakup, coupled with the shock and horror he experienced in WWI (where he was shot and nearly killed), led to some 
atypical behavior, including the commission of the doll (Hughes, 1986; Pulham, 2008).

In a letter to Moos, Kokoschka writes: "The hands and feet must be well articulated.

Take, for example, your own hand as a model. Or think of the hand of a well-groomed

Russian woman who, furthermore, rides a horse. And the foot, for instance, could be like that of a dancer" (Pulham, 2008, p.3).

Kokoschka's doll was designed to be sexually functional. He also shared his bed with the doll and took her out in the daytime (Hughes, 1986). Kokoschka's, "SelfPortrait with Doll" depicts the artist expressing his profound disappointment with the verisimilitude of the doll (see figure 3); subsequently, he destroyed the doll at a party. A website dedicated to the life and work of Alma Malher includes Kokoschka's description of the event:

...naturally, everyone in Dresden was gossiping about my strange carryings-on with a doll. Finally, after I had drawn it and painted it over and over again, I decided to do away with it. It had managed to cure me completely of my Passion. So I gave a big champagne Party with chamber music, during which Hulda exhibited the doll in all its beautiful clothes for the last time. When dawn broke I was quite drunk, as was everyone else - I beheaded it out in the garden and broke a bottle-of red wine over its head. (http://www.almamahler.at/engl/almas_life/puppet.html) 


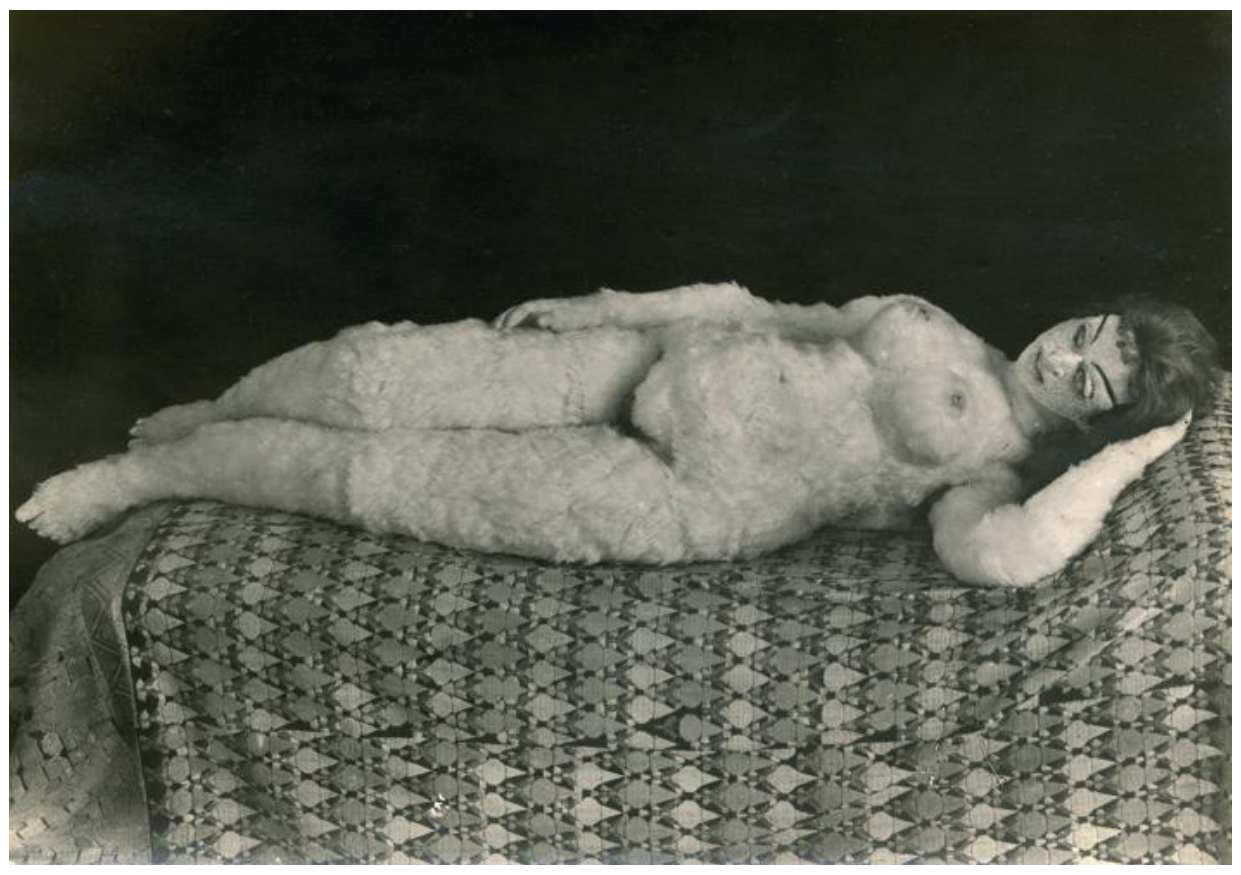

Figure 2

Puppenfetisch nach Alma Mahler, 1919, Vintage Prints, 10.5 x 15 cm, Privatbesitz, Dresden. 


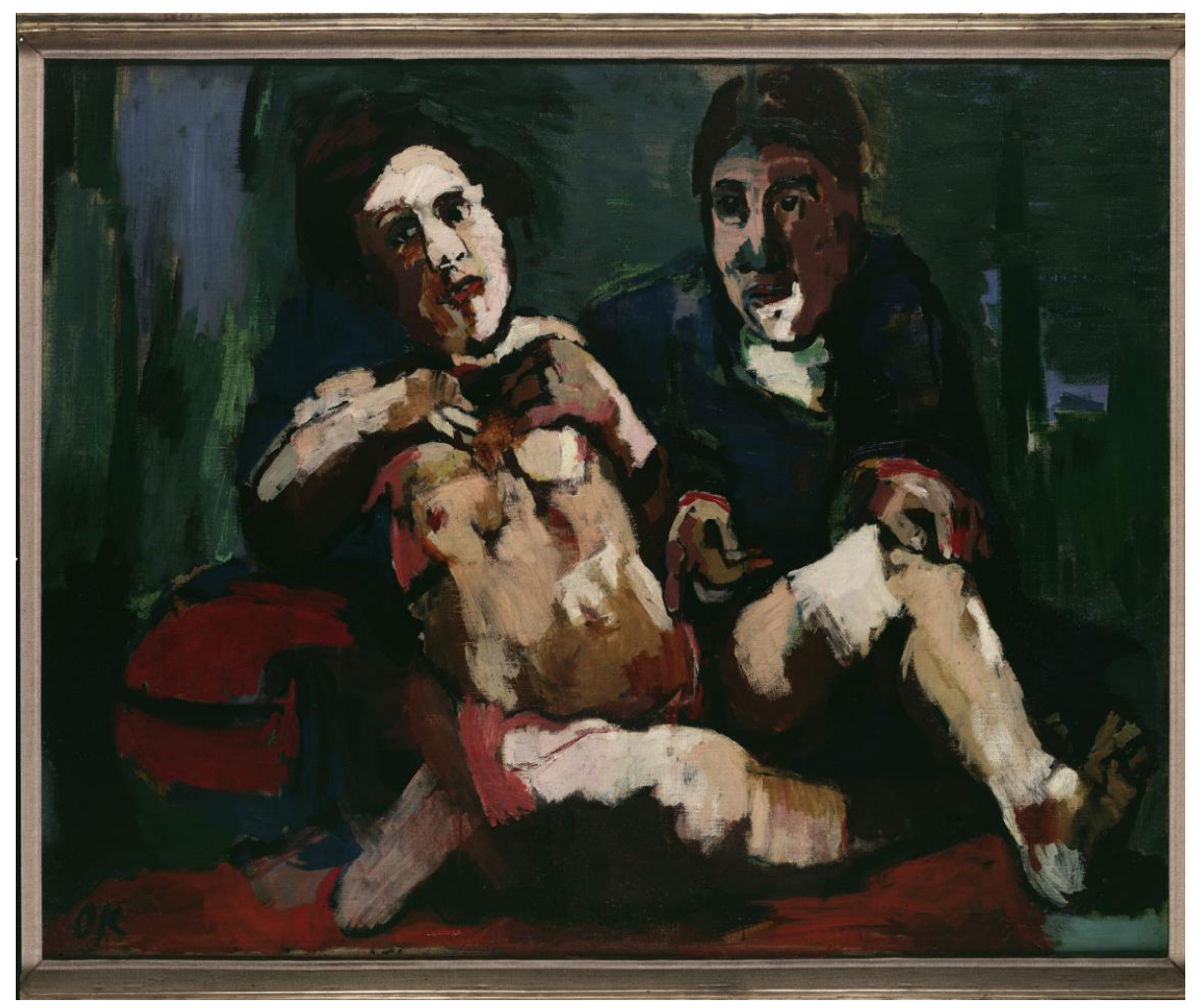

Figure 3

Oskar Kokoschka, Mann mit Puppe, Berlin, Nationalgalerie, Staatliche Museen zu Berlin, Foto: Jorg P. Anders

\section{Professional Attention}

The psychological community knows little about this burgeoning population.

Several reasons for this include population resistance, manufacturer resistance in disclosing sales information, language barriers, and a lack of professional literature and methodological issues in studying human sexual behavior and in investigating marginalized populations. Censorship has further limited access to material pertinent to the study of the modern sex doll-owner. The 1873 Comstock laws prohibited the mailing of obscene materials for decades. From the turn of the $20^{\text {th }}$ century until 1968 , sexual devices were illegal and sexology works "had restricted distribution during this time" in the United States (Moya, 2006, p. 15). Political fascism in Europe, beginning in the 
1930's, affected German and Austrian sex researchers, forcing many to shut down research and development institutes and flee their countries. The Berlin Institute for Sexual Science was destroyed by fascist gangs in 1933 (Meyenburg \& Sigusch, 1977).

The psychological community has contributed little to literature on the sex-doll phenomenon. The sex research at the turn of the $20^{\text {th }}$ century described the use of sex dolls and statues as a pathology, without supporting empirical evidence (Schewe \& Moreno, 2011). Iwan Bloch and Havelock Ellis likened statue love to necrophilia: "Closely allied to these necrophilist tendencies is the remarkable 'Venus statuaria'....apart from certain aesthetic motives...we have to do, for the most part, with the same motives that give rise to necrophilia—sadistic, masochistic, and fetishistic" (Bloch, 1908. p. 467).

In an interview by Scott for Metro Online, forensic psychologist and Leicester University lecturer Vincent Egan commented on doll-owners: "They need to think more about their relationships with the people they say they find sexually exciting," he says. "Perhaps they can't fantasize easily themselves and the dolls help." When contacted via email by this author to clarify his statements Dr. Egan said:

Any prosthesis is an adaptation to a problem (or perceived problem). Some people may use sex dolls due to disturbed attachments; others may simply not have attachments to start... For men, who may program their sexuality to rely on appearance via pornography, the appearance of the doll will become the key to the eroticism, rather than the (sometimes) emotional, playful, dynamic and interactive physicality of sex (Dr. Vincent Egan, personal communication, July, 2011).

Egan also says doll-owners need to build on relationships with humans as opposed to dolls or robots.

In contrast UCSF forensic psychologist and sex offender expert, Dr. Douglas Tucker, believes intercourse with a love doll does not signal anything particularly wrong 
or unhealthy, adding that he would hesitate to label men who enjoy sex with these dolls as pathological (Laslocky, 2005).

Dr. Tim Ring, the psychologist appearing on "My Strange Addiction," said to the featured doll-owner, "It makes you feel good...it doesn't hurt anyone, so knock yourself out." David Levy author of the book, Love and Sex with Robots, seeks to "counter skepticism” surrounding human-robot relationships, “... robot sex will become the only sexual outlet for a few sectors of the population: the misfits, the very shy, the sexually inadequate and uneducable. For some other sectors of the population, robot sex will be indulged in occasionally, an activity that supplements one's regular sex life" (Levy, 2008, n.p.).

Regarding specific diagnosis for the sexual use of human replicas there have been different opinions among investigators, Kraft-Ebbing refers to the behavior as pathological (1965/1978), Ellis described it as erotomania (1942), whereas Bloch (1908) and Hirschfeld \& Gibbs (1940) refer to the phenomenon as a fetish closely linked to necrophilia. Finally, Tabori (1969) relates the use of sex dolls to rubber fetishism.

On May 22, 2012, in a segment titled, "Men Who Love Their Doll," psychologist Mike Dow spoke on journalist Anderson Cooper's daytime talk show, Anderson, and described doll-owners as having "doll-fetishism" and further remarked, "how many of us have sexual fantasies about something? Well, you can have it in your head, or for some people, they want to take it to the next level. So that's what this is really about" (retrieved July 4, 2012, from http://www.andersoncooper.com/2012/05/21/dr-mike-dows-diagnosisdoll-fetish). 
Can a diagnosis be applied to sex-doll users according to our current diagnostic criteria? According to DSM-IV-TR diagnosis of paraphilia, the criteria for Paraphilia include, "intense sexually arousing fantasies, sexual urges or behaviors generally involving (1) nonhumanobjects, (2) the suffering or humiliation of oneself or one's partner, or (3) children or other nonconsenting persons that occur over a period of at least 6 months" (p. 568). Further, "paraphilia must be distinguished from non-pathological use of objects," and "behaviors are paraphilic only when they lead to clinically significant distress or impairment" (p. 568). According to doll forums, personal communications, and media interviews, at least some doll-owners report improvement in mood and general sense of well-being. A diagnosis of paraphilia would be unwarranted, without significant distress or impairment in functioning. Provided a doll-owner doesn't need sex doll in order to achieve sexual satisfaction, a diagnosis of a fetish would not be appropriate, either. Although some doll-owners may be described as having a foot fetish or partialism of some kind, most dolls are sold as a fully-articulated human form.

\section{Ethical Considerations}

In their paper, Schewe and Moreno (2011) cite some ethical and legal issues concerning sex doll-ownership and manufacturing of child-like dolls. Child dolls are not currently found for purchase in the United States, but are available through Japanese doll companies such as the Make Pure Mini dolls presented by the La Vie en Doll website. The manufacturing, marketing, distribution, and consumption of child sex dolls is another source of investigation, not to mention controversy. As noted earlier, U.S. manufacturers claim they don't produce child sex dolls. In other countries like Japan, however, they appear less taboo. In forensic circles, it's possible some might argue child sex dolls 
would be one way pedophiles could manage their sexual predilection for children; needless to say, there likely would be a chorus of responders arguing such allowances would only reinforce an already deviant and illegal sexual lifestyle. Either way, investigating this and other child sex doll phenomena poses unusual challenges.

As noted by Schewe and Moreno (2011) the US Protection Act of 2003 outlaws cartoons, drawings, sculptures, or paintings depicting minors engaging in sexually explicit conduct "which lacks serious literary, artistic, political, or scientific value." This law would seem to include sex dolls as sculptures; however, the law is ambiguous as to what constitutes "serious artistic value." Japanese manufacturers create child dolls, as mentioned previously. Japan also has a large comic book industry, "manga," where child-like characters are featured engaging in sexual activities. Japanese anime, or animation, also includes animated child sex scenes.

Also mentioned by Schewe and Moreno (2011), the U.S. convicted one man in 2006 of possession of child pornography because of his vast collection of Japanese manga (Kravets, 2009). Japanese child pornography laws do not include manga and anime images in their list of outlawed materials. Article 177 of the Japanese penal code puts the age of consent for sexual activity at 13 years-old. In the U.S., the age of consent is between 16-18 years-old, depending on the state.

\section{Research Questions}

The sex doll industry is a rapidly growing international phenomenon; however, to date there has been no empirical investigation into the types of characteristics associated with doll-owners including demographic information. There is much the psychological community does not know about doll-owners and the industry. We do not know how 
many doll-owners are in existence. Doll-owner personality characteristics, their demographic information, and attitudes towards sex and human intimacy largely remain unknown to the psychological community.

With these facts in mind, the purpose of this study is to increase our understanding of the modern sex doll owner. Specifically, several questions guided this study: 1. Who owns a sex doll? 2. What purpose does the doll serve? 3. How many sex dolls do doll-owners have? 4. What are the rates of mental illness among this population and what is their level of satisfaction with life? 5. Do doll-owners participate in psychotherapy? 6. Do doll-owners suffer from sexual functioning issues? 7. Do dollowners tell others about their sex doll?

\section{Hypotheses}

Several hypotheses emerged, guided by research questions, a review of the literature, media coverage, informal case studies, anecdotal evidence, and psychological opinions on doll-owners.

This investigator hypothesized that the demographics mentioned earlier should be similar to the survey's results; this sample of surveyed doll-owners from an online forum in English, are predominantly single, middle-aged, heterosexual White males. This investigator believes the primary purpose of sex-dolls is sexual. Due to the high price of sex-dolls, it is hypothesized that doll-owners typically own only one doll and that the number of sex dolls owns is positively correlated with income. It is hypothesized that levels of reported Depression and mental illness will be similar to US national averages. This investigator hypothesizes that $S W L S$ scores for this sample will not differ 
significantly from a $S W L S$ population value of similar demographic characteristics with regards to age, culture, sex. 


\section{CHAPTER TWO}

\section{Methods}

\section{Participants}

Participants for this study were recruited from an online doll-owner community forum. The forum is in English and the site reports around 2000 members. Seventythree respondents began the survey, 61 completed. Of the 61 completed surveys, $15 \%$ $(n=9)$ were male non-doll-owners who planned on purchasing a doll in the future, $10 \%$ $(n=6)$ were female doll-owners, and the remaining $75 \%(n=46)$ were male doll-owners. Sixty-three percent $(n=29)$ of male doll-owners in this sample live in the U.S., 13\% $(n=6)$ live in Canada, with the remaining 24\% $(n=11)$ living in France $(n=3)$, Germany $(n=3)$, U.K (n=2)., Australia (n=1), New Zealand $(n=1)$, and the Netherlands $(n=1)$. Due to the low number of female participants, most statistical analysis used only male-respondent data.

\section{Instruments}

A 45-item survey addressing demographic data such as participant annual income, sex, age, race, education, location, age, gender, and sexual orientation was constructed for this study. The survey was available online through www.surveymonkey.com and the link to the survey was posted to the online doll forum with a description of the survey and a request for participants. In addition to responding to general demographic questions, participants were asked to describe their relationship status, doll-ownership status, primary purpose for owning a sex-doll, and satisfaction with human and sex doll relationships. Participants were asked to complete questions concerning sexual satisfaction, performance, and to describe any dysfunctions they may experience. 
Participants were also asked whether they have participated in psychotherapy and/or been diagnosed with a mental illness during their lifetime.

A five question measure called the Satisfaction with Life Scale (SWLS) (Diener et al., 1985) was included in the survey. This scale was found to have moderately to strong correlations with several subjective well-being scales such as Campbell et al.'s semantic differential scale $(\mathrm{r}=.59-.75)$, the Differential Personality Questionnaire $(D P Q)(\mathrm{r}=$ .68), Fordycee's Percent of Time Happy Question $(\mathrm{r}=.58-.62)$, and Andrews and Whithey's D-T scale $(\mathrm{r}=.68)$ (Diener et al., 1985). Pavot and Diener (2008) reference six studies where coefficient alphas for the $S W L S$ ranged from .79 to .89 indicating favorable internal consistency. Further data derived from the $S W L S$ has been subjected to factor analysis as part of the original development of the scale. A single factor accounted for $66 \%$ of variance and these results have been replicated in subsequent studies (Pavot \& Diener, 1993). The $S W L S$ is narrowly focused to assess global life satisfaction and does not address related constructs such as positive affect or loneliness. The benefits of using this measure are its brevity, global properties, and evidence suggesting it is well suited for use with different age groups. The $S W L S$ has a wide cross-cultural research base which is necessary for use with an international pool of participants. This sample's SWLS scores were compared with scores from George (1991) where the respondents lived in the U.S., the mean age was $47.44(\mathrm{SD}=9.82)$ and $96 \%$ were male.

\section{Procedure}

Before beginning the survey, participants were prompted to read the informed consent guidelines and informed that participation in the survey was voluntary and strictly anonymous (see Appendix A). However, those participants wishing to be eligible 
for a $\$ 100$ (USD) gift card drawing were required to provide sufficient identifying information to win (email address). The drawing and award of the gift card prize were conducted through a third party unaffiliated with the survey website, ePrize, LLC. Identifying information was not connected to the survey. At no time was participants' personal information disclosed to investigators. The results of the survey were stored via surveymonkey.com and could be accessed at any time by this investigator. The survey was available to forum members for one month. Once data collection ended, the survey was closed and the raw data was downloaded into an SPSS program for analysis. 


\section{CHAPTER THREE}

\section{Results}

The internal reliability for the $S W L S$ was assessed before testing the hypotheses. Cronbach's alpha for the $S W L S$ was .848 , similar to those found by George (1991) where the Cronbach's alpha was .86. The internal reliability coefficient was determined to be sufficient (Cronk, 2012) to proceed with further statistical analysis.

$\mathrm{H}_{1}$ : The majority doll-owners sampled are: (a) males, (b) middle-aged, (c) White, (d) single, (e) employed, (f) hold a high school degree (or its equivalent) or higher, (g) identify sexual orientation as heterosexual.

Of the doll-owners who completed the survey, (a) 12\% (n=6) were female dollowners, and the remaining $88 \%(n=46)$ were male. The demographic data collected on the male doll-owners $(n=46)$ are as follows: (b) Mean age $=43,(\mathrm{sd}=11.5)$, the youngest was 20 oldest is 69; (c) 85\% identified as White ( $n=39)$; (d) Seventy-one percent $(n=33)$ reported being single; e) $67 \%(n=31)$ work 30 hours or more a week, and $65 \%(n=30)$ earn between $\$ 30,000-\$ 90,0000$ annually; (f) One hundred percent $(n=46)$ report holding a high school degree or higher; (g) Eighty-seven percent $(n=40)$ identified their sexual orientation as heterosexual.

$\mathrm{H}_{2}$ : The primary purpose of sex-dolls is sexual. Doll-owners experience sexual functioning issues at a greater rate with human partners than with sex dolls.

Seventy percent $(n=32)$ report one primary purpose of their doll is sexual stimulation, $30 \%(n=13)$ report companionship is a primary purpose of their doll, $17 \%$ $(n=7)$ report using their doll to enhance sex activities with human partner. Answers were not mutually exclusive. 
Forty-one percent $(n=19)$ report their primary sex partner is a doll and $37 \%$ $(n=19)$ percent of that group answered "yes" to the question of "Do you feel guilt, shame, or embarrassment about your sexual desires or activities with your primary partner." Thirty-one percent $(n=14)$ of this group reports sexual functioning issues with human partners versus $10 \%(n=5)$ of the group reporting sexual functioning issues (difficulty having an orgasm, becoming lubricated (wet), pain with sex, rapid or delayed ejaculation, having and/or keeping an erection when having sex). Sixty-three percent of this group rated the quality of their sexual experiences with sex dolls as "above average" to “excellent."

Forty-one percent of male doll-owners $(n=19)$ reported their secondary sex partner was a female doll and of that group, $15 \%(\mathrm{n}=7)$ responded yes to feeling shame, guilt, or embarrassment in relation to sex with dolls. Similar to the group whose primary sex partner is a female doll, $26 \%(n=12)$ of this group report experiencing sexual functioning issues with human partners and $15 \%(\mathrm{n}=7)$ report sexual functioning issues with their sex doll(s). Sixty-eight percent of this group rate their sexual experience with sex dolls as "above average" to "excellent."

\section{$\mathrm{H}_{3}$ : The majority of doll-owners own one doll. The number of dolls owned is}

\section{positively correlated with income.}

Sixty-one percent $(n=28)$ of doll-owners own one doll. Thirty-nine percent of male doll-owners $(n=18)$ own two or more sex dolls. A Pearson correlation was calculated examining the relationship between income and the number of dolls owned. A weak negative correlation that was not significant was found, $r=.062, p>.05$. Income is not related to the number of dolls owned by one individual. 


\section{$\mathrm{H}_{4}$ : Doll-owners are secretive about their use of sex dolls.}

In response to the survey question: "If you own a doll, with whom do you share this information with? Please check all that apply:" fifteen percent $(n=7)$ responded "no one," 35\% (n=16) marked "romantic partner," 35\% (n=16) marked "close friend(s)," $28 \%(\mathrm{n}=13)$ marked "family member(s)", $13 \%(\mathrm{n}=6)$ marked "neighbors," and 60\% $(n=27)$ marked "online community." Answers were not mutually exclusive.

\section{H5: Doll-owners have not participated in therapy with sex doll use as a} primary concern or behavior to change.

None of the doll-owners reported participating in therapy due to their use of sex

dolls. Thirty-three percent of male doll-owners $(n=15)$ reported participating in therapy; $11 \%(\mathrm{n}=5)$ reported having suffered from anxiety; 19.6\% $(\mathrm{n}=9)$ for depression; $9 \%(\mathrm{n}=4)$ for relationship/marital difficulties and only $2.2 \%(\mathrm{n}=1)$ for issues relating to sexuality.

\section{$H_{6}$ : Reported rates of depression will not differ from US national averages.}

Self-reported life-time prevalence of was Depression slightly higher than national average population value (US). Nineteen percent $(n=9)$ of male doll-owners report participating in therapy and/or having a diagnosis of depression during their life-time compared to a national average of $15.1 \%$ for life-time prevalence of depression in males in the U.S. A $z$ test comparing the proportions for depression between the sample proportion and the population proportion was calculated. It was hypothesized that the proportions are equal. No significant deviations from the hypothesized values was found between the two proportions $(\mathrm{z}=.844, \mathrm{p}>.05)$.

$\mathrm{H}_{7}$ : Male doll-owner $S W L S$ will be similar to a comparative population value. 
SWLS average score for the male doll-owners was 22.9 ( $\mathrm{sd}=6.15)$. A single sample t-test compared mean $S W L S$ for the sample with a larger population value of 24.15 (George, 1991). The sample mean of $22.9(\mathrm{sd}=6.15)$ was not significantly less than the population mean, $\mathrm{t}(45)=1.363, \mathrm{p}=.180$.

\section{Post Hoc Analysis}

Unplanned analyses suggest some differences between male and female respondents: females reported a significantly higher $S W L S$, lower rates of depression, and a greater percentage of females are either married or in a relationship compared with male respondent data. The female $S W L S$ score was in the "highly satisfied" range (score of 30-35), which is above average for individuals in western cultures (retrieved June, 2012 from

http://internal.psychology.illinois.edu/ ediener/Documents/Understanding\%20SWLS\%2 0Scores.pdf).

In post hoc analysis, an independent samples $t$ test comparing mean $S W L S$ of female and male doll-owners found significant difference between means of the two groups, $\mathrm{t}(50)=3.061, \mathrm{p}<.01$. The male doll-owner score was significantly lower $(m=22.913, s d=6.152)$ than female doll-owners $(m=30.666, s d=3.669)$. This is surprising as many studies have shown a strong convergence between life-satisfaction scores and the sexes, as pointed out in Diener \& Diener (1995). 


\section{CHAPTER FOUR}

\section{Discussion}

\section{Summary of Significant Results}

The doll-owners sampled appear to be primarily single, employed, middle-aged, White, heterosexual males. The demographic results are not surprising but it should be noted that if this survey was conducted on a Japanese online community, the racial demographics would be quite different than those found among English-speaking dollowners. Not all doll-owners are male; there were six female doll-owners who completed the survey, however due to the small sample size their data was separated from male dollowner data and discussed only in post hoc analysis.

Although some male doll-owners reported using their dolls for photography, companionship, and novelty, the majority doll-owners reported using their doll for sexual gratification and stimulation. Doll-owners do report issues in sexual functioning and at a greater rate when sexual activity involves a human partner. The majority of doll-owners report above average to excellent satisfaction levels for sexual stimulation when using their dolls which indicates sex doll use is an enjoyable experience.

Although feelings of guilt or shame and embarrassment occur for some dollowners, most in this sample share their doll-owning status with relatives, friends and neighbors at a higher rate than expected. The majority of doll-owners share this information with other doll-owners via internet communications, and only a few participants reported not disclosing their use of sex dolls to anyone.

Surprising to this investigator is the finding that $40 \%$ of male doll-owners own more than one sex doll. Considering the high price of the modern sex doll, this 
investigator expected to find that the number of dolls was positively correlated with annual income. This was not the case. According to several manufactures, some dollowners save for years for a sex doll and others continue to add to their collection of sex dolls over many years. The average income of doll-owners sampled is similar to US median household income of $\$ 50,020$ USD (according to the Current Population Survey results for January 2012 conducted by the US Census Bureau), with survey respondents reporting between $\$ 30,000$ and $\$ 90,000$ USD a year. After the initial hefty purchase, sexdolls are relatively inexpensive to maintain and one could certainly argue it is much less expensive to care for a sex-doll than to be in a romantic relationship with a human being considering the costs of food, gifts, rent, activities, etc.

\section{Professional Implications}

In contrast to the vague accounts of "statue love" described by early sexologists, there is now clear evidence that sexual use of human replicas is being practiced crossculturally and the manufacturing of the custom of sex dolls is an established industry. Although this phenomenon is unusual it is not blatantly pathological. The survey results suggest doll-owners are not only employed and educated, but also do not appear to suffer significantly from major mental illness and appear satisfied with their lives.

Adaptive features of sex doll-ownership are worth consideration by the psychological community. Anecdotal evidence suggests these dolls have brought relief, security, and happiness to their owners. Benefits of doll-ownership could be derived by those who are isolated from others, those with disabilities, or those who struggle with human attachment. Doll-owners have created a community online where they have developed friendships with others who share their enthusiasms. Doll-ownership has 
allowed artistic expression for those who film, photograph, and style their dolls. Dollowners who augment their human sexual relationships may have found greater satisfaction with their sex lives after the inclusion of a sex doll. Some doll-owners who have lost a spouse or partner have referred to their sex doll as a therapeutic transitional object.

In light of possible benefits of sex doll use, it is worthwhile to consider further applications for sex dolls, for those in isolated environments, for those with disabilities that may impede their ability to have satisfying sexual contact with others, and those who seek a safe way to express sexual fantasies they are unable to with human partners. Sex dolls carry no diseases and pose no risk of physical harm to users, unlike soliciting the services of a sex worker. It is possible sex dolls could be used for sex therapy to address various sexual functioning issues, much like the controversial intervention of using of human sexual surrogates in counseling.

As advances in technology and robotics continue to develop, we may see more and more individuals seeking out synthetic partners. This development may prompt the psychology community to consider the possibility that a preference for human-like partners, as opposed to human partners, may be an expression of a neosexuality, as opposed to pathology. Advances in robotics may one day produce human replicas so realistic as to be mistaken for human. A preference for a synthetic partner could become mainstream behavior and no longer a considered deviant.

Maladaptive features of doll-ownership must also be discussed. Doll-ownership may exacerbate withdrawal from human attachments, and ultimately impede individuals' ability to interact with others, maintain social phobias, and limit opportunities for growth 
and social learning. Dolls will never challenge their owners, and often embody an idealized version of a human being. For some doll-owners, this high level of control is comforting, but may make it difficult to manage the unpredictability of other people.

\section{Diagnostic and Treatment Implications}

Doll-ownership alone does not warrant a diagnosis of a paraphilia. Although some demographic trends were noted in this research, it bears repeating that doll-owners are individuals and are varied in their personal characteristics and social functioning. Where some doll-owners exclusively use sex dolls for solely sexual activity, others report infrequent sexual use of their dolls.

Survey results indicate doll-owners do/have participated in psychotherapies, but not for interventions addressing doll-ownership. Doll-ownership, for the most part, seems to be egosyntonic (consistent with one's ideal self-image). Some doll-owners reported participating in therapy due to relationship difficulties for grief issues, and for anxiety and depression. Although mental health professionals may see doll-owners in their practice, they might not be aware of their client's ownership status, as it is not the issue the client is interested in resolving.

What investigators may find in the future is that doll-owners suffer from a variety of mental illness, just as the general population does. Rates of depression among survey respondents are slightly higher than the national male averages for lifetime prevalence of Major Depression (Kessler et al., 2010), but not significantly different. Ten percent of respondents reported struggling with some general anxiety issues.

Interestingly, during post hoc analysis it was discovered that the rate of depression among those participants who do not own a doll but would like to, is 
considerably higher than current doll-owners. Fifty-five percent of non-doll-owners reported having participated in therapy and/or been diagnosed with depression. It is possible, and evidenced by anecdotal accounts, that these dolls might be helpful in alleviating various psychic complaints, such as loneliness or boredom. Perhaps rates of depression for some would decrease with the purchase of a sex doll.

$S W L S$ data for male respondents supported the hypothesis that there would be no significant difference among doll-owners compared with a group of similar age, sex, and culture (George, 1991). Male respondents reported a "slightly satisfied" average score (score of 23). Ed Diener (2006) describes the average score of life satisfaction in economically developed nations as between $20-24$. It would appear that doll-owners do not differ from other groups of middle-aged men in westernized cultures in regards to life satisfaction. Owning a sex doll does not indicate dissatisfaction with life.

\section{Sociocultural Implications}

Doll-owners have built an online community and established their own culture although they may come from a variety of cultural backgrounds and ethnicities. We must consider a social constructivist perspective and consider context when observing behavior. Within their cultural context, owning a doll is the standard practice, not a deviation from the norm. Quantitative surveys of sexual behavior, like this one, can offer only limited insights into social and cultural factors associated with different behaviors and offers no insight into the ways the behavior is shaped in different cultures (Abramson \& Herdt, 1990; Parker et al., 1991).

A multicultural view on collecting data does not place descriptive and qualitative research at the bottom of the methods hierarchy (Shaver, 2005), because to do so would 
deter researchers from studying minority populations altogether (Sue, 1999). Psychiatrist Dr. Ronald Mihordin describes research on sex doll-owners as an opportunity for discovery outside of clinical interviews and research protocols: "we have data from the people who are part of the culture...this is a unique opportunity to learn before the waters have been muddied by professional overlays" (Mihordin, 2012). Deviancy and abnormality are socially created constructs and we should approach doll-owners with respect to individuality and cultural sensitivity.

The information gathered in this study, although limited, still contributes to our knowledge of this current and poorly-understood phenomenon. If we demanded only controlled and quantitative research, we would have no information on this population at all. Understanding the characteristics of this marginalized population challenges professionals and laymen to look beyond "deviant" behavior and consider other areas of functioning before prematurely attributing specific pathologies to a population based on one factor (doll-ownership) alone.

\section{Methodological Issues and Limitations}

Methods of sampling such as snowball sampling, target sampling, and key informant sampling do not provide representative data (Shaver, 2005) but were necessary means of sampling in this case. To assuage the mistrust of investigators, several online doll-owning community members, familiar with investigators' previous research, vouched for experimenters in effort to recruit more participants. Target sampling also occurred in this case as the most visible doll-owners (online community members) were sampled, and less visible (not online community members) were under-sampled, further limiting the applicability of this study's results to the greater doll-owning population. 
Modern sex doll-owners have been targeted and reprimanded for their practices. An online forum titled "Something Awful" (www.somethingawful.com) targets dollowners, referring to them as "doll fuckers" and describing them as "pathetic losers," among other derogatory adjectives. Stigma and social desirability can impact the accuracy of information shared by participants. Self-reports among hidden populations are often distorted (Abramson, 1990). Moral commentary on sexual deviations from a conservative norm is a strong deterrent for open and unbiased discussions on the use of sex dolls. It is a challenging endeavor to gather enough subjects for assessment and to establish trust with a population wary of being studied for fear of persecution and moral judgment.

Initially, participation in the survey was limited and after posting the survey on the forum the feedback received from the online community was that there were concerns about the survey's legitimacy and the intentions of this investigator. Doll-owners who had spoken with this researcher in the past were willing to vouch for this researcher's credibility, and the result was an increase in participating respondents. See Appendix B for detailed reactions to the survey posting. In reaction to perceived or feared marginalization and stigma concerns, responses may have been altered to reflect a higher level of functioning and mental well-being, as the survey did not include measures to control for social desirability effect on responses.

Recognizing the dearth of information concerning modern sex dolls, it may be that sex doll-owners have rarely if ever sought out a mental health professional for information or treatment regarding this phenomenon. It is unknown at this time whether the ownership of sex dolls is in any way egodystonic (inconsistent with one's ideal self- 
image). Assessment tools and diagnostic criteria to assess mental illness were absent from this study. Depression rates were self-reported and therefore cannot provide any definitive information on depression rates among this population. It is also possible that "depression" may not have cultural equivalence within this international sample.

Although the SWLS can indicate a general satisfaction with life it does not measure loneliness or relationship satisfaction. To draw conclusions on these related life satisfaction constructs would require the use of specific measures designed for that purpose.

Modern sex-doll-ownership is a cross-cultural phenomenon as mentioned earlier. Language barriers may prevent investigators at this time from sharing information or accessing foreign media coverage and doll manufacturer websites and online communities. This study was limited to English-speaking online sex doll community members, and at this time results cannot be indicative of doll-owner characteristics crossculturally. Cultural norms, beliefs, and language will influence responses to variable sexual practices. Terminology such as sex, sexual dysfunction, and homosexuality can have different meanings depending on cultural context. Abramson and Herdt (1990) provide an example: “a society may not have a noun category for 'sex' or 'sexuality,' such as those in English. Rather, forms of sociosexual relationships may be constructed linguistically (e.g., sexual activity) or metaphorically (e.g., "to play around")" (p. 222).

Finding credible sources concerning sex doll-owner information poses several challenges. Collecting data on human sexual functioning has not been a priority of scholars (Abramson,1990). Antiquated psychopathology texts add little to our understanding of the modern sex doll-owner. Unusual sources provide most of the 
available information on the topic of sex doll-ownership, and their level of reliability is often unknown. There is a lack of standardized terms used to describe sex dollownership and the use of sex dolls, even among those within the community.

The size and scope of the doll-owning population is unknown; therefore, no reliable representative sample is available at this time. These factors are common challenges in researching minority populations and when gathering information on sexuality, as mentioned in Malacad \& Hess (2011).

\section{Future Directions}

Obtaining larger sample sizes is critical to increasing our understanding of this population. Obtaining a larger sample size of female doll-owners is also necessary, as some significant differences between male and female doll-owners were found in this study, but due to small $\mathrm{n}$ sizes statistical inferences are limited. To further investigate the pathological assumptions of sex doll-ownership, incorporating standardized psychometric tools and conducting qualitative clinical interviews might garner greater understanding and individual differences among this population. By situating behavioral data within a wider social and cultural context, qualitative research may offer an important framework for the comparative analysis of data on sexual behaviors (Parker et al., 1991).

In addition, qualitative analysis of online forum content will further inform researchers of cultural practices and beliefs within this community. Future research might employ comparative cross-cultural investigations to determine cultural differences and similarities among doll-owners. Lastly, to address the possible adaptive and/or therapeutic use of sex dolls, researchers might examine the individual's well-being and emotional and psychological functioning pre- and post- sex doll purchase. 


\section{Conclusion}

From statues to silicon, humankind has created synthetic lovers for thousands of years. Rumored accounts of "statue love" have been replaced by documentaries and television interviews featuring individuals who own and love high-end life-sized sex dolls. This study aimed to introduce the sex-doll phenomenon to the psychological community and to describe this little-known population of doll-owners. Survey results indicate most doll-owners from an English speaking online forum are White, middleaged, single males who are employed, and identify as heterosexual. Although some demographic trends are noted, not all doll-owners are alike; females as well as individuals of different races and ethnicities also own sex dolls. Sex dolls appear to be primarily used for sexual stimulation. However, there are some who describe a deeper emotional connection to their dolls and many who own more than one. On the surface, it appears doll-owners are neither significantly better nor worse in terms of psycho-sexual functioning and life satisfaction than the general population. Anecdotal evidence suggests the doll-owning community has fears of being stigmatized and targeted by outsider groups, which may have created evaluation apprehension and deterred respondents from answering honestly, or else deterred entirely some from participating. Professional implications of this study call upon the psychology community to investigate this population further with clinical interviews and appropriate psychometric tools. Future research into the adaptive and maladaptive qualities of sex doll use is needed. Lastly, the psychology community is urged to consider doll-owners within a sociocultural context before labeling sex doll use as pathology. 


\section{References}

Abramson, P. (1990). Sexual science: Emerging discipline or oxymoron? Journal of Sex Research, 27(2), 147-165.

Abramson, P. , \& Herdt, G. (1990). The assessment of sexual practices relevant to the transmission of aids: A global perspective. Journal of Sex Research, 27(2), 215232.

Adler, M.G. \& Fagley, N.S. (2005). Appreciation: Individual differences in finding value and meaning as a unique predictor of subjective well-being. Journal of Personality, 73, 79- 114.

Bloch, I. (1908). The sexual life of our time: In its relations to modern civilization. New York: Allied Book Company.

Bolicki, J \& Cutlip, M. (Producer). (2011, January 26). Episode 8 [Television series episode]. In My Strange Addiction [Television series episode]. United States: Discovery-The Learning Channel.

Cary, H.N. (1922). Erotic contrivances: appliances attached to, or used in place of, the sexual organs. Chicago, IL: Privately printed.

Cronk, B.,C. (2012).How to use SPSS: A step-by-step guide to analysis and interpretation. (7th ed.).Glendale, CA: Pyrczak Publishing.

Diener, E. , \& Diener, M. (1995). Cross-cultural correlates of life satisfaction and selfesteem. Journal of Personality and Social Psychology, 68(4), 653-663.

Diener, E., Emmons, R. A., Larsen, R. J., \& Griffin, S. (1985). The satisfaction with life scale. Journal of Personality Assessment, 49, 71-75. doi:10.1207/s15327752jpa4901_13. 
Duran Duran. (1997). Medazzaland. [CD]. United States: Capital-EMI.

Ellis, H. (1942). Studies in the psychology of sex (Vol. I). New York: Random House.

Ferguson, Anthony. (2010). The sex doll: A history. London: McFarland and Company, Inc.

Flintoff, T. \& Raphael, M. (Producers). (2006). Guys and dolls [Motion picture documentary]. [Directed by Nick Holt]. [Narrated by Mark Strong]. United Kingdom: North One- BBC America

Galbraith, P. (2008, May 17). Plastic fantastic: Japan's doll industry booming. Japan Today. Retrieved June 2011, from http://www.japantoday.com/category/lifestyle/view/plastic-fantastic-japans-dollindustry-booming

Gebhard, P.H., Johnson, A.B., Kinsey, A.C. \& Institute for Sex Research. (1979). The Kinsey data: Marginal tabulations of the 1938-1963 interviews conducted by the Institute for Sex Research. Philadelphia: Saunders

George, J. (1991). Time structure and purpose as a mediator of work-life linkages. Journal of Applied Social Psychology, 21(4), 296-314.

Gillespe, Craig (Director). (2007). Lars and the Real Girl [Motion Picture]. [Written by Nancy Oliver]. [With Ryan Gosling, Emily Mortimer, Paul Schneider \& Patricia Clarkson]. United States: Metro-Goldwyn-Mayer

Hersey, G. (2006). Falling in love with statues: Artificial humans from Pygmalion to the present. Chicago, IL: The University of Chicago Press.

Hirschfeld, Magnus. (1940). Sexual pathology: A study of derangements of the sexual instinct, New York, Emerson Books 
Hughs, R. (1986, July 21). Art: In London, a visionary maestro. Time. Retrieved July 4, 2011 from http://www.time.com/time/magazine/article/0,9171,961789-2,00.html

Itagaki, Azusa. (2011). Inside the doll-house: Fashion and the creation of identity (Unpublished master's thesis). Stockholm University, Centre for Fashion Studies, Sweden.

Keller, B., Krivicke, M., (April, 2012). Commercial perspective on sex doll-owners. In Kessler, R. , Birnbaum, H. , Bromet, E. , Hwang, I., Sampson, N. , et al. (2010). Age differences in major depression: Results from the national comorbidity survey replication (ncs-r). Psychological Medicine, 40(2), 225-237.

Krafft-Ebing, Von R. (1978). Psychopathia sexualis: With especial reference to the antipathic sexual instinct. Briarcliff Manor, NY: Stein and Day. (Original work published 1965)

Kravets, D. (2009, May 28). U.S. manga obscenity convictions roils comics world. Wired. Retrieved July 26, 2011 from http://www.wired.com/threatlevel/2009/05/manga-porn/

Laslocky, M. (2005, October 11). Just like a woman. Salon. Retrieved October, 2010 from http://www.salon.com/life/feature/2005/10/11/real_dolls/index3.html

Lenz, N. .n.d. The Borghild project: A discreet matter of the III Reich. Retrieved from http://www.borghild.de/indexe.htm

Levy, D. (2008, January 16). My Robot, my love. National Sexuality Resource Center. Retrieved April 5, 2011, from http://nsrc.sfsu.edu/article/my_robot_my_love Lewis, C.A., Dorahy, M.J., \& Schumaker, J.F. (1999). Depression and life satisfaction among Northern Irish adults. Journal of Social Psychology, 139, 533-535.

Maeda, T. (2007, July 18). Japan's lonely hearts turn to dolls for sex, company. Reuters. 
Retrieved October, 2010 from http://www.reuters.com/article/2007/07/18/usjapan-sex-dolls-idUSSP10422420070718.

Malacad, B. L., \& Hess, G. C. (2011). Sexual behavior research using the survey method: A critique of the literature over the last six years. European Journal of Contraception and Reproductive Health Care, 16, 328-335.

Meyenburg, B. , \& Sigusch, V. (1977). Sexology in West Germany. The Journal of Sex Research, 13(3), 197-209.

Mihordin, R., (April, 2012). Professional perspective on sex doll-owners. In J.K. Moreno (Co-Chair) and S. Valverde (Co-Chair), Hello dolly! Personal, commercial, and professional perspectives on sex doll-owners. Symposium conducted at the $92^{\text {nd }}$ meeting of the Western Psychological Association, Burlingame, CA.

Moreno, J.K. (Co-Chair) and S. Valverde (Co-Chair), Hello dolly! Personal, commercial, and professional perspectives on sex doll-owners. Symposium conducted at the $92^{\text {nd }}$ meeting of the Western Psychological Association, Burlingame, CA.

Moya, Cynthia A. (2006). Artificial vaginas and sex dolls: an erotological investigation (Unpublished doctoral dissertation). The Institute for Advanced Study of Human Sexuality, San Francisco. California.

Parker, R. , Herdt, G. , \& Carballo, M. (1991). Sexual culture, hiv transmission, and aids research. Journal of Sex Research, 28(1), 77-98.

Pavot, W., \& Diener, E. (1993). The affective and cognitive context of self-reported measures of subjective well-being. Social Indicators Research, 28, 1-20. doi:10.1007/BF01086714. 
Pavot, W., \& Diener, E. (2008). The satisfaction with life scale and the emerging construct of life satisfaction. The Journal of Positive Psychology, 3(2), 137-152.

Pulham, P. (2008). The eroticism of artificial flesh in Villiers de l'isle Adam's l'eve future. 19: Interdisciplinary Studies in the Long Nineteenth Century, 7, 1-22. Retrieved from http://19.bbk.ac.uk/index.php/19/article/viewFile/486/346.

Roxxxy sex robot: world's first sex robot can do more than chat. (2010, March 18). Huffington Post. Retrieved May 28, 2011, from http://www.huffingtonpost.com/2010/01/10/roxxxy-sex-robot-photowo_n_417976.html

Schewe, S., \& Moreno, J.K. (2011). Modern sex dolls and their owners: Assessment, diagnostic, and treatment implications. Paper presented at the annual meeting of the American Psychological Association, Washington, DC.

Scobie, A. \& Taylor, A. J. W. (1975). Perversions ancient and modern: I. agalmatophilia, the statue syndrome. Journal of the History of the Behavioral Sciences, 11(1), 4954.

Scott, L. Flexible friendship. Metro Online. Retrieved July 23, 2011 from http://www.metro.co.uk/lifestyle/10322-flexible-friendship\#ixzz1RkEq880

Shaver, F. (2005). Sex work research: Methodological and ethical challenges. Journal of Interpersonal Violence, 20(3), 296-319.

Siberry, J. (Writer/Producer). (2010, February). Strange love [Television series episode]. In Taboo [Television series episode]. United States: Nation Geographic Channel Slocum-Gori, S. , Zumbo, B. , Michalos, A. , \& Diener, E. (2009). A note on the 
dimensionality of quality of life scales: An illustration with the satisfaction with life scale (SWLS). Social Indicators Research, 92(3), 489-496.

Somaiya, R. (2010, January 11). Computer love: new 'lifelike’ sex doll is still weird, not lifelike. Gawker. Retrieved April 2011, from http://gawker.com/5445184/newlifelike-sex-doll-is-still-weird-not-lifelike.

Steger, M.F., Frazier, P., Oishi, S., \& Kaler, M. (2006). The meaning in life questionnaire: Assessing the presence and search for meaning in life. Journal of Counseling Psychology, 53, 80-93.

Sue, S. (1999). Science, ethnicity, and bias: Where have we gone wrong? American Psychologist, 54(12), 1070-1077. doi:10.1037/0003-066X.54.12.1070

Tabori, P. (1969). The humor and technology of sex. New York: Julian Press Inc.

Tucker, K. , Ozer, D. , Lyubomirsky, S. , \& Boehm, J. (2006). Testing for measurement invariance in the satisfaction with life scale: A comparison of Russians and North Americans. Social Indicators Research, 78(2), 341-360.

White, M. (1978). The statue syndrome: Perversion? fantasy? anecdote? Journal of Sex Research, 14(4), 246-249.

Wolf, A. (2010, August). Libidos on the high seas. Avantoure. Retrieved from http://www.avantoure.com/index.php/whats-hot-avantoure-magazine/2244-libidosex. 
Appendix A

\section{INFORMED CONSENT TO PARTICIPATE IN SEX DOLL POPULATION SURVEY}

A research project on modern sex doll-owners is being conducted within the graduate program of the Psychology Department at Cal Poly State University, San Luis Obispo. The purpose of this research is to better understand the modern sex doll-owner/enthusiast, particularly with respect to their attitudes, beliefs, behaviors, and general demographic information.

Procedure: Participants will be asked to complete an online survey. It should take approximately 15 minutes to respond to all items. Please respond only once.

Participation is voluntary and you may discontinue at any time without penalty. You may also omit any items on the questionnaire(s) you prefer not to answer.

As you complete the survey, a separate sweepstakes entry form page opens. Survey participants can enter for a chance to win through this separate form while keeping their survey responses anonymous. The prize is a $\$ 100 \mathrm{Gift}$ Certificate to Amazon.com. Participants are only eligible for one entry in the gift card drawing. This sweepstakes is limited to those residing in the United States, age 18 years or older. The survey will be active for 30 days; the drawing will take place at the close of the study where ePrize will draw a random winner and deliver the reward. An email is sent to the winner with the reward information.

Confidentiality: Participation is strictly anonymous. The identity of participants will be unknown to the investigators and other participants. Completing the survey online and participating in the gift card drawing will not provide investigators any identifying information. No identifying information will be included in the published study. You will not be required to provide your name or any other unique identification unless you wish to be included in the $\$ 100$ gift card drawing. Personal information will not be available to the investigators and will not be attached to survey responses.

Potential Risks: There should be no risks for participants beyond those associated with everyday life. The nature of this survey is personal and addresses areas of sexuality, including sex dolls. Other topics include life satisfaction, annual income, and physical, mental, and emotional health. If you are uncomfortable answering questions related to any of these topics, please do not participate. The exercise should not cause any discomfort and/or inconvenience. If the nature of the subject matter causes distress, please contact the researchers and/or 1800273TALK (provides free $24 \mathrm{hrs} /$ day support to those in crisis and/or those suffering from emotional distress).

Potential Benefits: By participating in the study you may learn more about yourself, the research process, and the human condition.

If you have questions regarding this study or would like to be informed of the results when the study is completed, please feel free to contact J.K.

Moreno, $\mathrm{PhD}$, at (805) 7562805. If you have questions or concerns regarding the manner in which the study is conducted, you may contact Dr. Steve Davis, Chair of the Cal Poly Human Subjects Committee, at 7562754, sdavis@ @alpoly.edu, or Dr. Susan Opava, Dean of Research and Graduate Programs, at 7561508, sopava@ calpoly.edu. 
You must be 18 years of age in order to participate in this research. You are not required to answer any of these questions and your participation is completely voluntary. By clicking the NEXT button and completing the survey you are consenting to participate in the study. If you do not wish to participate, please exit the survey now.

Please retain this consent cover form for your reference, and thank you for you're your consideration. 


\section{Appendix B}

\section{Responses to Survey Posting:}

Just so you know, all dolls are not used for Sex and some dolls are used for much more than that. There you have my input for your survey. You would not understand any more than that and I feel you already have your finding made up anyway.

Since I rarely, if ever, have sex with dolls and never with humans, not a lot of my answers will be of help to the study. In my opinion, only an in-depth interview can get to the meat of the matter.

Having been a member of the doll community for some time I have observed more calm, reason, function and level headedness and less extreme thought and behavior within it than I have observed in the , so called 'normal', everyday society we live.

When the results are tallied, there will be no research funding forthcoming. We're not that different from sports car collectors. We show off our prized possessions. Driving them gives us a thrill. We take it very badly when they break.

I respect and appreciate what [the researchers] are trying to do. I don't want to have a stigma associated with something as simple and understandable as wanting to take care of my needs in the absence of a woman in my life just because I wanted to do so with a type of aid that offers a more vivid simulation and ultimately more fulfillment than other less effective and less stigmatized aids. 
